\title{
ASSESSMENT OF THE PROSPECTS OF SPRINGS IN WESTERN KAZAKHSTAN FOR USE IN RELIGIOUS TOURISM
}

\author{
Kazhmurat M. AKHMEDENOV* \\ M. Utemisov West Kazakhstan University, Department of Geography, \\ N. Nazarbaeyv Ave 162, 090000 Uralsk, Kazakhstan, e-mail: kazhmurat78@mail.ru
}

Citation: Akhmedenov, K.M. (2020). ASSESSMENT OF THE PROSPECTS OF SPRINGS IN WESTERN KAZAKHSTAN FOR USE IN RELIGIOUS TOURISM. GeoJournal of Tourism and Geosites, 31(3), 958-965. https://doi.org/10.30892/gtg.31304-527

\begin{abstract}
This work is devoted to the study of sacred springs in Western Kazakhstan, assessing their current state and prospects for use as objects of religious tourism. From the surveyed 75 springs of the West Kazakhstan region in the period 2012-2017, 20 springs corresponding to these parameters were identified. A field survey of famous Holy springs was conducted and their assessment as objects of recreation and cult worship was carried out. It is shown that on the territory of the region. Holy springs are characterized by a level of recreational and cult ratings from low to very high, with the predominance of a group of sources with a high rating, which indicates their excursion and pilgrimage attractiveness. Their sanitary and technical condition was assessed, the flow rate, $\mathrm{pH}$, and hydrochemical composition of spring waters were determined, and spring passports were compiled. It is established that the sanitary condition is dominated by springs with a good rating. The presence of gazebos on the territories adjacent to the springs, their widespread improvement, make the springs promising objects of religious tourism of excursion, educational and pilgrimage directions.
\end{abstract}

Key words: springs, religious, tourism, sanitary, capture, holy places, ritual, pilgrimage, West Kazakhstan

\section{INTRODUCTION}

The tourism potential of Kazakhstan is rich and diverse and has unique opportunities for the development of almost all types of tourism, from educational, related to visiting cultural and historical sites to adventure, environmental and other active types of tourism (Yessimova et al., 2016; Mazhitova et al., 2018; Beketova et al., 2019; Kabdrakhmanova et al., 2019; Koshim et al., 2019; Koshim et al., 2020; Kerimbay et al., 2020; Akbar et al., 2020). Due to its unique nature, geographical location, and history, Western Kazakhstan has a fairly high potential for tourism development, however, tourist sites are still little known to the international community and the domestic market (Ramazanov et al., 2003; Sergeeva, 2011; Kubesova, 2015; Yegemberdiyeva et al., 2018). A huge number of various water bodies are concentrated on the territory of Western Kazakhstan, and some of them are of interest for the development of tourism and recreation. In particular, attention is being paid to religious tourism, which includes both pilgrimage and religious tourism with an excursion and educational orientation.

Research on the development of religious tourism is underway in Saudi Arabia (Ascoura, 2013; Triki, 2019), India, Japan (Ivanova et al., 2018), Norway (Jørgensen et al., 2020), France (McIntosh et al., 2020), Scotland, Canada (Wilson, 2020), Uzbekistan, Tajikistan (Bunakov et al., 2019), Russia (Krylov, 2011; Kuznecova et al., 2019), Armenia (Tovmasyan, 2016), Iran (Baranchikov, 2019) and other countries.

At the same time, there are few publications on the use of springs as objects of religious tourism. Works on Holy sources have been published in several regions of the Russian Federation (Belohvostikov, 2007; Anisimova, 2008; Bedula, 2010), they contain legends and legends related to the sources, the history of temples and monasteries that arose near them, and specific instructions about the location. In some works, the current state of Holy springs is considered, the peculiarities of their sanitary and technical condition are identified, and their assessment as objects of recreation and cult worship is given (Orekhova et al., 2016, 2017; Serak, 2017; Absalyamova, 2019; Di Puppo and Schmoller, 2019). Kazakhstan is not water-scarce in terms of total water supply per capita (MFA, 2016). However, the uneven distribution in space and time, in combination with excessive and often uncontrolled withdrawal for irrigation, create water scarcity (Zhupankhan et al., 2018).

At present, springs have a great recreational popularity, as a wide variety of near-water landscapes of springs attracts the attention of the population, and the water sources are widely used for balneological and drinking purposes, especially intensively used sources located in places that are well accessible to the population. In this regard, it is important to conduct a comprehensive assessment of the tourist potential of springs. At the same time, special attention should be paid to aesthetic properties, since they usually contribute to their attractiveness. In connection with the different tasks of types of religious tourism, there is a problem of evaluating the possibilities of using individual springs in various tours. In pilgrimage tourism, it is important to use the spring for religious rites. Excursion and educational tourism is based on the recreational attractiveness of objects.

\section{MATERIALS AND METHODS}

Field surveys of 75 springs were conducted in 2012-2017 (Figure 1). Reconnaissance survey was conducted to assess the state of spring accumulation area and to specify the spring's location. Fixation of the spring on a topographic map has been done. Area, to be examined at each source, is $0.25 \mathrm{~km}^{2}$. Total examination area is $300 \mathrm{~km}^{2}$. Scope of work for the examination was fully accomplished together with the examination of flood bed, spring bolson, description of degree of peat formation, photographing. Water was sampled from all 75 springs in order to study their chemical composition and to evaluate the suitability for drinking. Analysis of indicators of sanitary-technical condition of the investigated water bodies, the determination of flow rate, $\mathrm{pH}$, temperature and oxygen: $\mathrm{pH}$ directly in the field, nitrate content, turbidity, hydrocarbons, chlorides, sulphates, calcium, magnesium, total hardness, sodium and total mineralization in an accredited laboratory. The results of hydrochemical indicators were compared with the normative sanitary rules of the SanPiN of the Republic of Kazakhstan dated March 16, 2015 No. 209 "Sanitary and epidemiological requirements for water sources, places of water intake for drinking purposes, drinking water supply and places of cultural and domestic water use and water safety" (2015).

Methodological bases for assessing the recreational significance of springs and the prospects of their use for religious purposes were developed from a geosystem perspective by a group of well-known specialists (Sivokhip, 2005; Petin and Novykh, 2009; Katkova, 2013;

\footnotetext{
${ }^{*}$ Corresponding author
} 
Novykh \& Demchenko, 2013; Orekhova et al., 2016, 2017), whose works were used by the author. The assessment of indicators of the sanitary and technical condition of the spring and its feeding area was based on the classification developed by the Moscow state geological exploration Academy (Shvets et al., 2002).

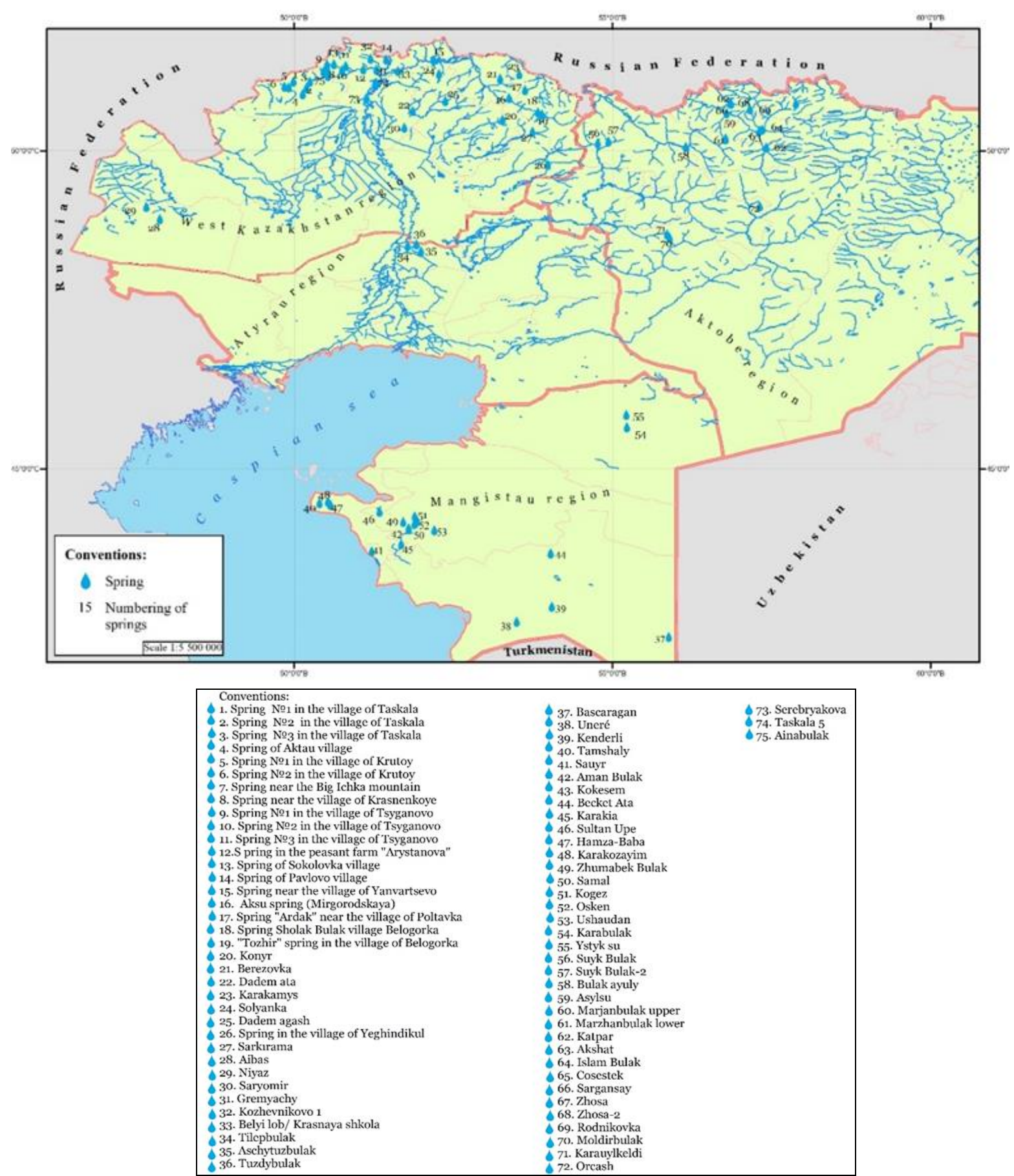

Figure 1. Location of springs in Western Kazakhstan (Source: a map with the legend compiled by the author and based on his own field data)

It covers three indicators: the technical condition of the capture Changed into capture, the sanitary condition of the spring and the sanitary condition of the feeding area. The technical condition of the capture indicator includes capture, technical equipment of the spring (a place to rest) and a place for water sampling. It can take three values:

1) Good - there is a capture and it is equipped with a place to rest and take water;

2) Satisfactory - at least one of the listed parameters is missing;

3) Unsatisfactory-the spring has only a capture, or it is not equipped.

Sanitary condition of the spring - an indicator that takes into account the contamination of the territory adjacent to the spring. If the territory of the spring location is cleared of household and industrial waste, the sanitary condition of the spring is called well, if there is household waste-satisfactory, and if placed near the spring of industrial waste - unsatisfactory. The sanitary condition of the spring feeding area is an indicator that takes into account the contamination of the spring's catchment area. If the feeding area of the spring is located within green areas, it is called good; if it is located on the territory of residential areas-satisfactory; unsatisfactory sanitary condition of the feeding area of the spring is characterized by the territories of industrial enterprises and landfills. The final assessment of the sanitary and technical condition of the spring is based on the lowest indicator (Orekhova et al., 2016). 
In the method of evaluating the potential of springs for use in recreational and religious purposes includes score and the following: the presence of religious buildings; the presence of elements of ritual and ceremonial activities; aesthetics; landscape features spring-fed ravine; the presence and type capturing device; water quality; flow rate; frequency of attendance source; free access to the spring; the equipment places; ensuring sanitary and hygienic requirements when using a spring; the presence on the territory of household waste and other wastes. Each parameter was evaluated from 0 to 1 point, and the maximum score could reach 10 points. Based on the total score obtained for both scales, the following evaluation criteria were used: $0-2$ points - very low (unsatisfactory); $2.5-4$ points - low; $4.5-6$ points - average; $6.5-8$ points - high; 8.5-10 points - very high. The results of the assessments were included in the passports of the Holy springs. This method has been used by us in the field survey of springs in Western Kazakhstan for a number of years; in particular, some of the results of the assessment were reflected in publications (Akhmedenov and Idrissova, 2018; Akhmedenov and Idrissova 2019).

\section{RESULTS DISCUSSIONS}

The veneration and sacralization of mountain ranges, rocks, caves, trees, and water sources, which is part of the traditional consciousness, has been known since ancient times. This worship of objects of nature as a relic was preserved by most of the Turkic peoples who adopted Islam, Christianity, and Buddhism, as evidenced by numerous works of ethnographers. Different aspects of the sanctity of water in the Turkic and Kazakh cultures are well developed in the works of Poyarkov (1891), Konshin (1901), Shulembayev (1975), Potapov (1991), Stasevich (2012), Tokhtabayeva (2017) and many others. When restrictions on religious worship were lifted in the 1990s, people flocked to shrines, reviving and rediscovering religious practices that never completely died out. They continue to do so today (Lymer, 2004). The cult of Holy places of natural origin is an integral part of the practice of pilgrimage to revered sites, which, in turn, has become one of the main features of the local (regional) form of Islam (Edelbay, 2012).

Pilgrimage to the Holy springs organically combines Islamized elements (reading the Koran, prayer, appeal to the moral foundations of Islam, sacrifice, etc.) and such pronounced pre-Islamic and non-Islamic forms of rites as an appeal to the spirits of the ancestors / aruahs who guard this place, "knot" magic, animism (worship of water, earth, wind, sun), etc. At present, it has become a tradition to worship "Holy places", which is a remnant of pre-Islamic beliefs (Basilov, 1992). Springs in Western Kazakhstan have healing properties and are places of pilgrimage. These springs and their spring tracts have fences, and springs and surrounding areas are regularly cleared. The map diagram (Figure 1) shows the location of all the studied springs in the period 2012-2017. The springs are located unevenly: 3 in the Atyrau region, 36 in the West Kazakhstan region, 17 in the Aktobe region and 19 in the Mangistau region. Of the 75 studied sources, 20, or 26.6\% can be attributed to promising objects of religious and sacred tourism: Becket Ata, Dadem ata, Dadem agash, Sultan Upe, Sarkirama, Aksu, Akbulak, Bolshaya Ichka, Tamshaly, Sauyr, Moldirbulak, Cosestek, Sargansay, Islam Bulak, Asylsu, Karakozayim, Samal, Tilepbulak, Aschytuzbulak, Tuzdybulak (Figure 1). Analysis of the parameters for assessing the sanitary condition of the spring shows that some of them can be easily adjusted, while others are almost impossible to change (Table 1).

Table 1. Assessment of the sanitary and technical condition of sacred springs in Western Kazakhstan (Data source: Personal original data, and also Akhmedenov and Idrissova, 2019)

\begin{tabular}{|c|c|c|c|}
\hline \multirow[t]{2}{*}{ Evaluation parameter } & \multicolumn{3}{|c|}{ Share of springs, $\%$} \\
\hline & good & satisfactory & unsatisfactory \\
\hline $\begin{array}{l}\text { The technical condition of the } \\
\text { structure }\end{array}$ & $\begin{array}{l}50 \\
\text { (Becket Ata, Dadem ata, Dadem agash, Islam Bulak, Asylsu, } \\
\text { Moldirbulak, Cosestek, Sargansay, Karakozayim, Akbulak) }\end{array}$ & $\begin{array}{l}\text { (Bolshaya Ichka, Sultan } \\
\text { Upe, Sarkirama, Aksu) }\end{array}$ & $\begin{array}{l}30 \\
\text { (Samal, Sauyr, Tamshaly, Tilepbulak, } \\
\text { Aschytuzbulak, Tuzdybulak) }\end{array}$ \\
\hline $\begin{array}{l}\text { Sanitary condition of the } \\
\text { spring }\end{array}$ & $\begin{array}{l}70 \\
\text { (Becket Ata, Dadem ata, Dadem agach, Sultan Upe, } \\
\text { Sarkirama, Islam Bulak, Asylsu, Bolshaya Ichka, Tamshaly, } \\
\text { Sauyr, Karakozayim, Tilepbulak, Aschytuzbulak, Tuzdybulak) }\end{array}$ & $\begin{array}{l}30 \\
\text { (Samal, Aкsu, Aкbulak, } \\
\text { Moldirbulak, Cosestek, } \\
\text { Sargansay) }\end{array}$ & 0 \\
\hline Sanitary condition of the spring & 50 & 20 & 30 \\
\hline
\end{tabular}

Table 2. Characteristics of hydrochemical indicators of springs in Western Kazakhstan

Data source: (personal original data, and also Akhmedenov et al., 2013; Idrissova et al., 2017)

\begin{tabular}{|c|c|c|c|c|c|c|c|c|c|c|}
\hline $\begin{array}{l}\text { Name of the } \\
\text { spring }\end{array}$ & $\mathrm{pH}$ & $\mathrm{NO} 2-, \mathrm{mg} / \mathrm{l}$ & NO3- $\mathrm{mg} / 1$ & $\begin{array}{c}\mathrm{HCO} 3- \\
\mathrm{mg} / \mathrm{l}\end{array}$ & $\mathrm{Cl}-, \mathrm{mg} / \mathrm{l}$ & $\begin{array}{c}\mathrm{SO} 42-, \mathrm{mg} / \\
1\end{array}$ & $\mathrm{Ca} 2+, \mathrm{mg} / 1$ & $\begin{array}{l}\mathrm{Mg} 2+ \\
\mathrm{mg} / 1\end{array}$ & $\begin{array}{c}\text { Total hardness, } \\
\text { mg-EQ/1 }\end{array}$ & $\begin{array}{c}\text { Mineralization, } \\
\mathrm{mg} / 1\end{array}$ \\
\hline Dadem ata & 7.61 & 0.24 & 0.00 & 945.50 & 325.00 & 238.70 & 5.20 & 4.90 & 0.00 & 2020 \\
\hline Dadem agash & 6.75 & 0.11 & 2.00 & 55.00 & 6.00 & 37.00 & 18.00 & 9.00 & 0.00 & 130 \\
\hline Sarkirama & 7.75 & 0.00 & 0.80 & 250.10 & 14.85 & 58.02 & 55.00 & 37.70 & 0.00 & 310 \\
\hline Aksu & 7.44 & 0.01 & 5.22 & 228.70 & 36.28 & 169.00 & 0.73 & 2.43 & 5.70 & 346 \\
\hline Akbulak & 6.42 & 0.03 & 0.10 & 201.30 & 155.00 & 97.00 & 80.00 & 36.00 & 7.00 & 541 \\
\hline Bolshaya Ichka & 6.27 & 0.00 & 0.00 & 103.70 & 17.50 & 43.20 & 36.00 & 0.00 & 1.75 & 179 \\
\hline Tamshaly & 8.38 & 0.00 & 0.66 & 274.50 & 128.10 & 195.10 & 78.00 & 73.20 & 10.00 & 1036 \\
\hline Becket Ata & 7.51 & 0.00 & 0.30 & 189.10 & 1629.80 & 1645.60 & 222.00 & 129.60 & 21.90 & 5754 \\
\hline Sultan Upe & 7.92 & 0.00 & 0.13 & 341.60 & 900.20 & 958.80 & 150.00 & 150.00 & 20.00 & 3691 \\
\hline Karakozayim & 7.40 & 0.00 & 0.14 & 219.60 & 242.00 & 376.10 & 98.00 & 61.20 & 10.00 & 1077 \\
\hline Samal & 7.00 & 6.30 & 0.06 & 195.20 & 96.00 & 193.40 & 62.00 & 37.20 & 6.20 & 625 \\
\hline Moldirbulak & 7.58 & 0.15 & 0.10 & 401.30 & 33.25 & 114.55 & 49.63 & 10.88 & 3.35 & 560 \\
\hline Islam Bulak & 7.60 & 0.30 & 0.00 & 427.00 & 96.00 & 147.00 & 52.00 & 44.40 & 6.30 & 702 \\
\hline Asylsu & 7.10 & 0.60 & 0.00 & 170.80 & 12.00 & 48.50 & 55.00 & 9.00 & 3.50 & 225 \\
\hline Cosestek & 6.29 & 0.00 & 0.00 & 142.25 & 37.75 & 111.95 & 57.85 & 9.75 & 3.55 & 325 \\
\hline Tilepbulak & 6.90 & 0.00 & 0.02 & 274.50 & 22500 & 126.0 & 2000 & 3840 & 3300 & 33684 \\
\hline Aschytuzbulak & 7.05 & 0.03 & 0.10 & 125.50 & 18410 & 53.50 & 3055 & 3799 & 3280 & 27480 \\
\hline Tuzdybulak & 7.13 & 0.01 & 0.10 & 282.35 & 22800 & 128.00 & 2075 & 3910 & 3500 & 33832 \\
\hline SanPiN RK № 209 & $6-9$ & 3.3 & 45 & not the norm & 350 & 500 & not the norm & not the norm & $7-10$ & $1000-1500$ \\
\hline
\end{tabular}




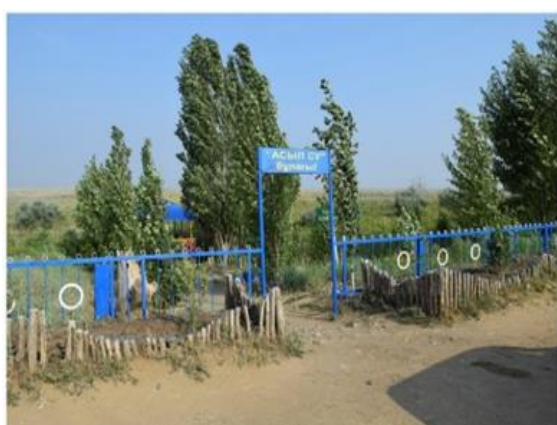

A

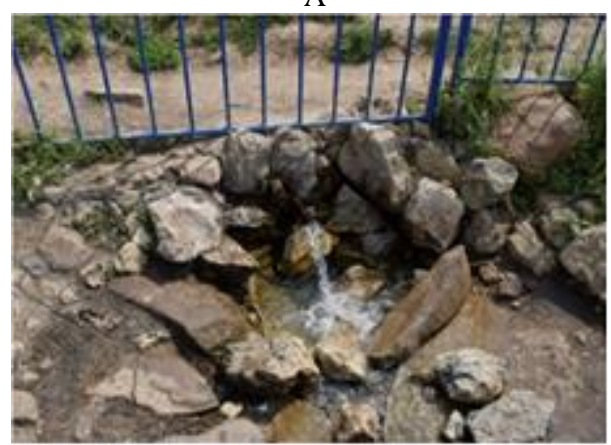

$\mathrm{D}$

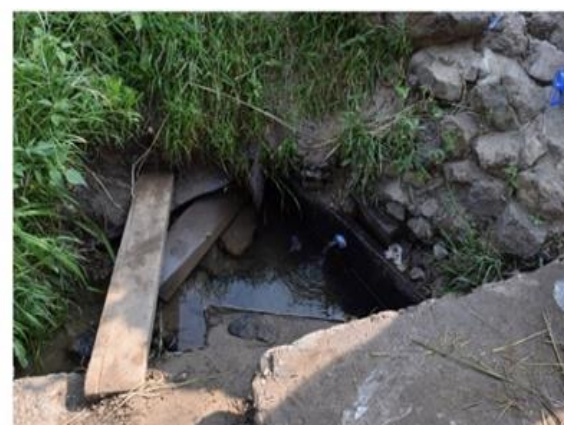

$\mathrm{B}$

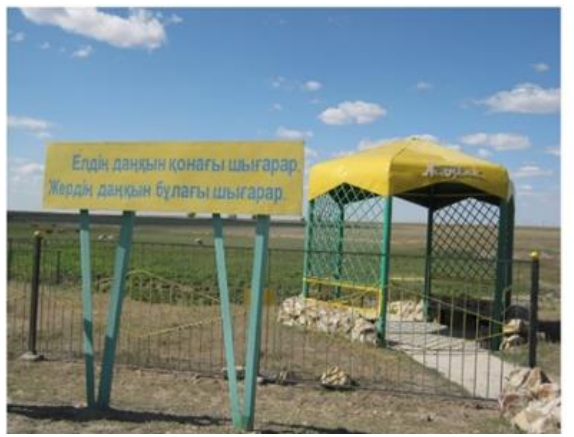

$\mathrm{E}$

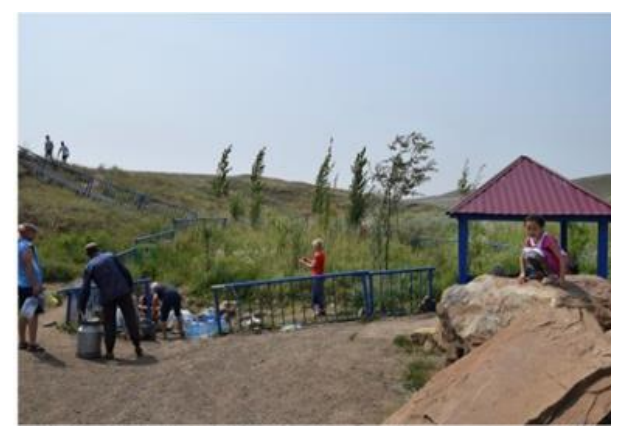

$\mathrm{C}$

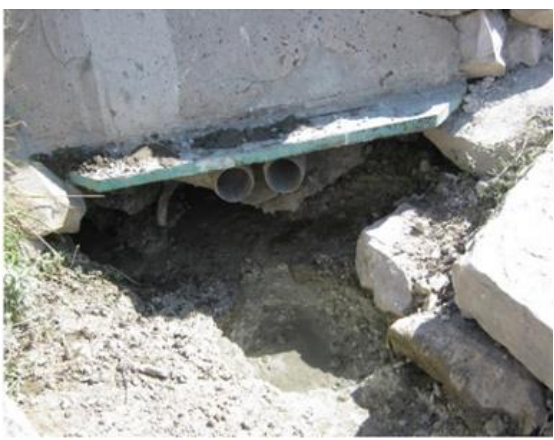

$\mathrm{F}$

Figure 2. Examples of well-maintained springs in Western Kazakhstan: A - fence and arbor of Asylsu spring; B - capture of Asylsu spring;

C - fence and arbor of Islam Bulak spring; D - capture of Islam Bulak spring; E - fence and arbor of Akbulak spring; F - capture of Akbulak spring

So the Sanitary condition of the spring can be made good even from unsatisfactory, by cleaning the waste area near the spring. The TSC can be changed by reconstructing the spring. At the same time, to transform the Sanitary state of the region from satisfactory to good, it is necessary to "remove" the residential area where the spring is located, which is hardly possible and appropriate. An assessment of the sanitary condition of the spring showed that most of the studied springs (50\%) have this indicator classified as good (table 1). This is due to their location away from localities. The satisfactory and unsatisfactory assessment of a number of springs is due to the state of capture and the presence of household waste. According to the Sanitary condition of the spring, good springs prevail among the Holy sources (Figure 2).

Earlier we conducted research on the hydrochemical composition of some springs in Western Kazakhstan (Akhmedenov et al., 2013; Idrissova et al., 2017). It should be emphasized that the drinking value of spring water requires a separate discussion, since the areas where springs are located and their catchment areas are often contaminated with human waste, which can lead to contamination of groundwater. However, local residents remain strongly convinced of their cleanliness and advantages over tap water.

This misconception is even more pronounced if we are talking about Holy springs, and therefore it is necessary to control the quality of spring water. The determination of the flow rate of the studied springs showed a wide variety of this parameter, ranging from 0.002 to 1.02 $1 / \mathrm{s}$. The $\mathrm{pH}$ of the waters of the studied springs varies from 6.27 to 8.38 , which corresponds to a neutral reaction (Table 2).

During the study, the excess of nitrites from the established standard MPC $-3.3 \mathrm{mg} / \mathrm{l}$ was recorded only in the spring water of Samal (1.9 times); the value of chlorine was exceeded from the established value of MPC-350 mg/ 1, in the spring waters of Sauyr 1.2 times, Becket Ata 4.6 times, Sultan Upe 2.5 times, Tilepbulak 64.2 times, Aschytuzbulak 52.6 times and Tuzdybulak 65.1 times (Table 2).

Sulphates were exceeded from the established MPC value of $500 \mathrm{mg} / 1$ in the spring water of Becket Ata and Sultan Upe by 3.29 and 1.9 times; the total hardness was almost 2 times exceeded also in the spring waters of Becket Ata and Sultan Upe, and a significant excess was established in the spring waters of Tilepbulak by 330 times, Aschytuzbulak by 328 times and Tuzdybulak by 350 times. The excess of MPC was recorded in terms of total mineralization $(1500 \mathrm{mg} / \mathrm{l})$ in the spring waters of Dadem ata by 1.3 times, Becket Ata by 3.8 times, Sultan Upe by 2.6 times, Tilepbulak by 22.4 times, Aschytuzbulak by 18.3 times, and Tuzdybulak by 22.5 times, respectively (Table 2 ). In general, in Western Kazakhstan, as such, pollution of spring waters is not observed in most cases, since they are located far from residential areas and agricultural use. Risk factors are: location in a locality, location in the lower part of the slope, presence of an active residential area or cultivated areas higher in the terrain, low flow rate, low level of development, which allows water to enter the water pollution from the surrounding area. Visual assessment of the sanitary state of the region also allows you to determine trends in the danger of water pollution by pollutants. Attention is drawn to the fact that 11 springs are landscaped, which is quite appropriate to ensure the cult function of the Holy spring.

When evaluating the prospects of springs for use in religious purposes, the indicator of the presence of elements of ritual and ceremonial actions in the springs is highlighted. The practice of veneration of these sacred spring tracts is regulated, and table 3 shows an analysis of traditional elements of veneration in the springs of Western Kazakhstan (Table 3).

Table 3. Evaluation of the prospects of springs for use in religious purposes based on the presence of elements of ritual and ceremonial actions in the sacred springs of Western Kazakhstan (Data source: personal original data)

\begin{tabular}{|c|c|c|c|}
\hline \multirow{2}{*}{ Evaluation parameter } & \multicolumn{3}{|c|}{ Share of springs, $\%$} \\
\hline & good & satisfactory & unsatisfactory \\
\hline Observance of the form of clothing, ritual cleanliness (mental and physical cleansing) & 50 & 20 & 30 \\
\hline Reading prayers (verses from the Koran) & 100 & 0 & 0 \\
\hline Attributes of a place of worship ("nodular magic») & 100 & 0 & 0 \\
\hline Ritual use of water from the source (drinking, face washing) & 100 & 0 & 0 \\
\hline Overnight at the facility & 50 & 20 & 30 \\
\hline $\begin{array}{l}\text { The presence of a caretaker - chirakchi and the conductor of the ritual on the spring (healer, bucks, etc.) } \\
\text { and accompanying stories (rules, history and related folklore) }\end{array}$ & 25 & 0 & 75 \\
\hline
\end{tabular}


From table 3 it is seen that the bulk items include: compliance with dress codes, ritual purity, prayers, attributes, places of worship, the worship of water source and overnight stay at the facility, the presence of the caretaker - chirakchi and conductor of the ritual at the spring. Almost all of these elements are "standard" forms of pilgrimage to sacred natural objects among Kazakhs (Levshin, 2007). Usually a sacred place consists of a tree, a water source, and the grave of a Holy person (Abramson and Karimov, 2007). In the countries of Central Asia and the Muslim countries of the Russian Federation, a water source (spring, well, house) and a religious buil ding (Mazar) are interconnected (Rakhimov and Terletsky, 2006). For example, there is a grave of the Holy girl "Kyz Aulie" near the Aschytuzbulak spring in Atyrau region, which is associated with a local legend (Figure 3).

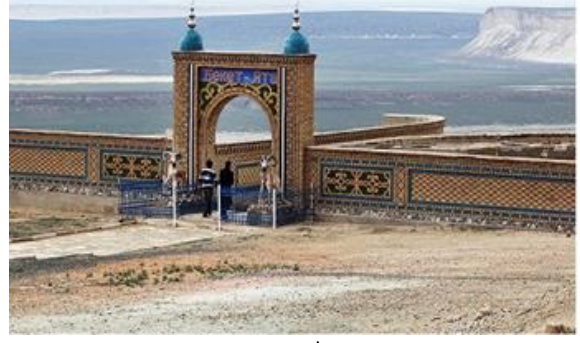

A

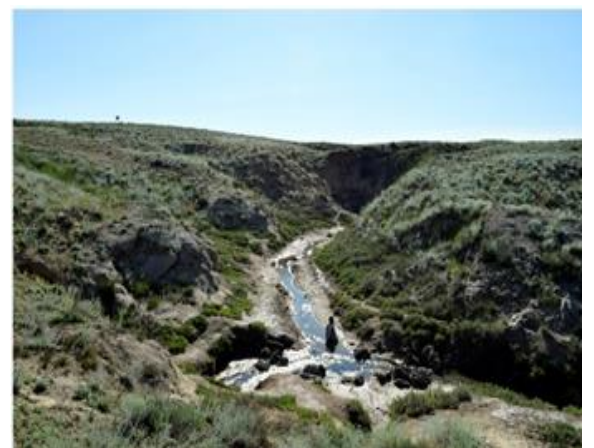

D

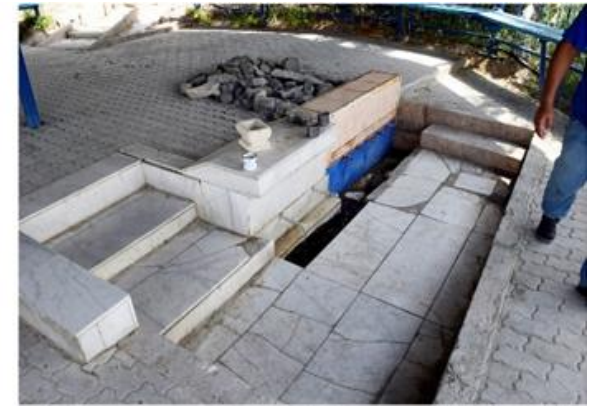

B

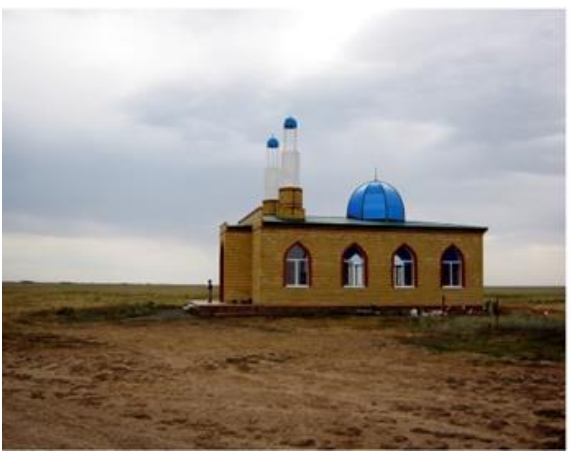

E

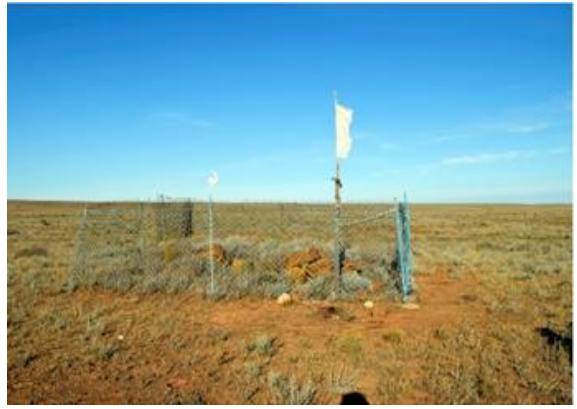

$\mathrm{C}$

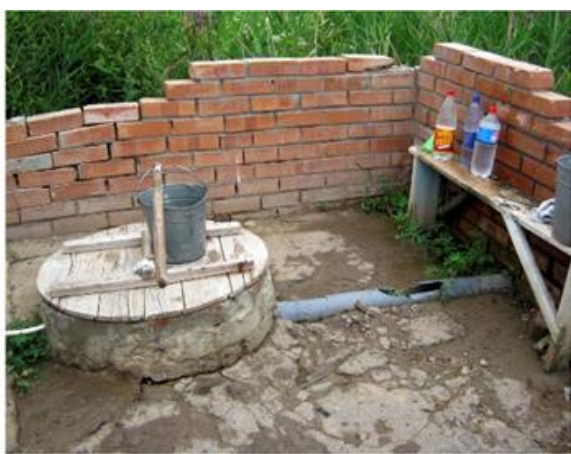

$\mathrm{F}$

Figure 3. Famous Holy places of Western Kazakhstan with springs. a-Becket Ata religious complex;

b-Becket Ata spring; c-grave of the Holy girl "Kyz Aulie"; d- Aschytuzbulak spring; e- Dadem ata mosque; f- Dadem ata spring

A significant feature of the life of the population of modern Central Asia is the growing interest in Mazars - "places of worship" associated with the names of Muslim Hazrat "saints", both real and belonging to the category of legendary characters. The saints left a good memory for their descendants, and after their death their qualities and virtues only increased in the eyes of the living, and the burial place quickly acquired a sacred character and became an object of pilgrimage (Terletskiy, 2007; Larina, 2016). For example, water bodies (wells, springs) that are widespread throughout Bashkortostan are named after the saints.

This is probably due to the preservation of the pre-Muslim cult of water in the Bashkirs. According to the views of Bashkirs, the sources associated with the name of the Saint are healing (Bukharova, 2017). At present, the visit of believers to these places of worship is widespread (Rakhimov and Terletsky, 2006; Idiatullov, 2018). At the same time, the range of practiced elements has significantly expanded to date. The so-called "knotting magic" - tying scraps of trees and shrubs, and in the absence of these, their analog-tuga (wooden pole) - a practice characteristic of the whole of Central Asia. Many researchers of this tradition note that in Central Asia, tying cloth ribbons around the tugh was practiced mainly on the graves of saints or those equated to them (Islamic tradition) (Terletskiy, 2009).

Part of the tradition of veneration of sacred objects has become the practice of hanging on the branches of nearby trees and bushes ribbons of white cloth (rags, less often parts of clothing), as symbols of hope for the fulfillment of desires (Figure 4).

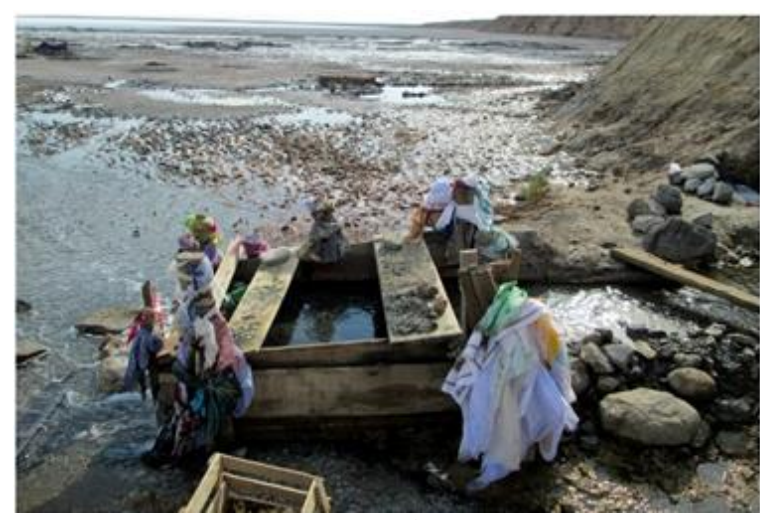

A

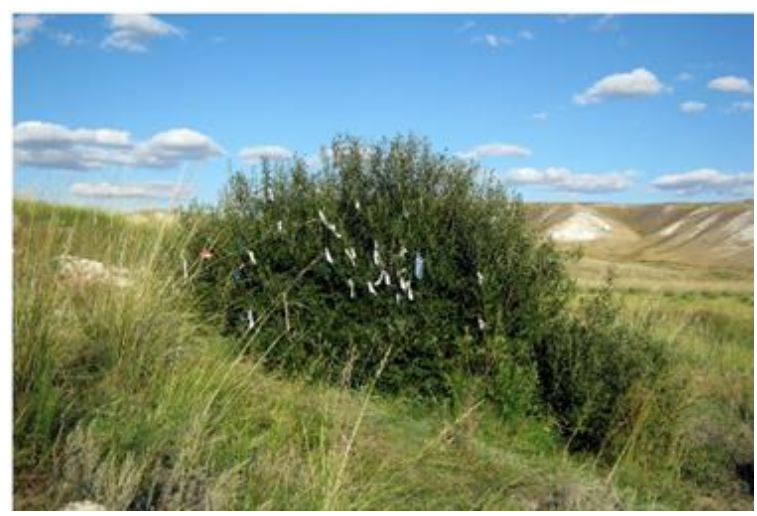

$\mathrm{B}$

Figure 4. Some Holy springs of Western Kazakhstan. A - flaps of fabric on the capture elements at the Tilepbulak spring; B - tying bushes with rags at the Aksu spring

This practice is universal and quite widespread among many peoples, including the population of Central Asia. Among the Holy places are "specialized" shrines, that are visited for healing from specific diseases. Most often, such shrines include all sorts of Holy springs, water 
from which, according to the tradition, relieves from stomach diseases, skin diseases, infertility, etc. (Stasevich, 2012). Many Holy places in Central Asia are not marked by any buildings. The only indication is pieces of cloth tied on tree branches (Lymer, 2004). Today, the tradition of tying cloth ribbons, in addition to a specific sacred object (fence of the grave, tree, etc.), has also begun to extend to all nearby objects. Now often use offerings in the form of fabric items (a piece of white cloth - actic, scarves - oramala, etc.).

In neighboring Central Asia, the religious authorities prohibit the use of ribbons at sacred sites, while many people do not comply with these instructions (Abramson \& Karimov, 2007, p.320). For example, of the springs we have studied, the most visited in the West Kazakhstan region is the Dadem ata spring. The spring is located not far from the burial site of Dadem ata, which was revered as a Saint among Muslims. In fact, he was called Auliye Jumagazy Hazrat. It is known that he was born at the end of the XVIII century. Nearby is a small house for pilgrims, a separate spacious namazkhana (Figure 3). According to the established tradition, everyone who passes along this road tries to visit the grave of Dadem ata and collect water from the source, which is considered to be medicinal. And the main thing is to collect it with you, so that you can drink it later as medicine. Life-giving water never deteriorates, even after a few years. The source is located at the Ankaty river. According to the legend, this well was dug by Dadem ata himself, the water in it is of exceptional purity, and it never freezes. Many who seek healing try to pour this water all over them in order to be spiritually cleansed. To do this, a shower room was installed nearby. Due to the large flow of people, the sanctuary of Dadem ata was registered in the justice authorities in 2009 as the Dadem ata Foundation.

In the Mangystau region, there is an underground mosque of Sufi Becket Ata on the Ustyurt plateau in the Oglandy tract (Figure 3). Becket Ata chose the path of a wandering Sufi, but returned to Mangistau at the end of his life. The wise man gave health to the infirm people, reconciled the warring parties, and opened a madrasah where he taught children. To this day, the people's path to the mosque of the sage is not overgrown. The underground mosque is organically inscribed in the thickness of the chalk mountain a light hole is cut in the dome of the Central room. The mosque is located in the middle tier of a massive rock that slopes down into a deep ravine overgrown with bushes. The mosque is one of the famous places of pilgrimage in Kazakhstan. Near the mosque there are springs and wells that were used by Becket Ata. Pilgrims who spend the night near this cave see prophetic dreams that suggest a way out of critical situations.

The spring Islam Bulak is located in the Aktobe region at the foot of one of the hills of the Mugodzhar hill, along the route "Western Europe- Western China". Fenced, well equipped, has a gazebo, captioned with an iron pipe. A striking example of improvement of a roadside spring. Every day people come to this spring with various dishes to stock up on clean water (Figure 2).

According to local legends, the springs of Western Kazakhstan have healing properties. Often people passing by springs stop, quench their thirst with clean, cold water, make wishes, hang pieces of white cloth on a tree and collect water for further use for medicinal purposes. Due to the constant flow of visitors, the surrounding area of the objects is being improved: there are fences, entrances to springs. The healing function of revered springs is usually not emphasized, it is not always the main one (but it always accompanies them), hiding behind the General sacred attitude to a particular place or source. However, the revered springs differ significantly in status and in the breadth of pilgrimage to them: the spring may be known only in one district or a small circle of neighboring regions, and may be revered in General in Kazakhstan. The degree of veneration of modern springs depends, first of all, on the scale of the religious Shrine next to which it is located.

\section{CONCLUSION}

Western Kazakhstan attracts pilgrims with its history and the presence of many sacred architectural monuments; however, an important role in the development of pilgrimage tourism is played by natural springs, most of which are considered healing. The region has a large number of Holy springs, but, unfortunately, not all are well- maintained. The most effective method to attract more pilgrims is to develop new routes. Due to the increased attention to the recreational use of territories, one of the directions of tourism development may be religious, including both pilgrimage and sightseeing. The "Holy springs", which are widely represented on the territory of Western Kazakhstan, have a great recreational potential in this direction. Holy springs are located in various natural and climatic zones and landscape areas. On the Poduralsky plateau-9, on the General Syrt -2, Mangyshlak-4, on Ustyurt-2, the Caspian lowland-3. Most of them are related to Poduralsky plateau. In terms of sanitary and technical condition, the leading springs are rated "good" - 50\%, due to their location far from settlements within natural landscapes; the share of springs rated" satisfactory» is $20 \%$.

The studied sources are characterized by a neutral reaction of the medium within 6.2-7.6, with the exception of water from the Tamshaly and Cosestek spring tracts with an alkaline reaction. The optimal pH of drinking water is from 7.0 to 8.0. The degree of acid -base indicators, determined by the concentration of hydrogen ions, forms the $\mathrm{pH}$ parameters, which are normal for drinking water, according to the SanPiN rules, are 6-9 units. According to this indicator, Kazakhstan's standards almost do not differ from the EU Directive-6.50 - 9.50 and from the requirements of the US environmental protection Agency (USEPA)-6.50 - 8.50.

The total salinity of water corresponds to sanitary and hygienic standards, except for water from the spring tracts of Dadem ata, Sauyr, Becket Ata, Sultan Upe, Tilepbulak, Aschytuzbulak, Tuzdybulak. At the same time, water from the springs of Tilepbulak, Aschytuzbulak, Tuzdybulak in the vicinity of Lake Inder in conjunction with balneological resources of the lake has a huge sanatorium-tourist-recreational potential. The waters of the surveyed springs mostly correspond to the SanPiN RK No. 209 in terms of nitrate content: the average content was 0.3; the maximum permissible concentration was recorded at the Samal spring. The increase in the concentration of nitrates in the water of this spring is due to the lack of infrastructure, which allows the water to receive pollution from the surrounding area.

Holy sources are characterized by their use for religious purposes. The prospects of using springs for religious tourism of excursion and educational orientation increase such elements of arrangement as fencing, gazebos and possibly fonts.

At the springs Sauyr, Becket Ata, Sultan Upe, Tilepbulak, Tuzdybulak, Ashytuzbulak, it is necessary to install signs warning the population about exceeding certain parameters in the waters of the springs and recommending the use of water for ablutions, but not for drinking. It is necessary to develop springs, they are sources of non-centralized water supply, create targeted programs by the decision of regional Executive bodies, and find public and private sources of funding. Not only the source itself, but also the territory adjacent to it (a zone of sanitary protection within a radius of $100 \mathrm{~m}$ from the sources) require improvement, this is a kind of indicative zone of cleanliness and order. The recreational rating of the Holy springs of the studied region varies from low to very high, the total share of springs with a high and very high rating is $50 \%$. The cult rating of the Holy springs of Western Kazakhstan also varies from low to very high, the total share of springs with a high and very high rating was $70 \%$. In Western Kazakhstan, there are springs with the highest possible cult rating of 10 points - Becket Ata spring (Mangistau region) and Dadem ata spring (West Kazakhstan region).

\section{Acknowledgements}

This article was prepared as part of the Science Committee grant funding of the Republic of Kazakhstan Ministry of Education and Science within the project named "Development of technology and methodology for the assessment and certification of spring water in Western Kazakhstan with a view to their protection and rational use" (state registration №0112RK00502). 


\section{REFERENCES}

Abramson, D., \& Karimov, E. (2007). Sacred Sites, Profane Ideologies: Religious Pilgrimage and the Uzbek State. - Everyday Life in Central Asia. Past and Present, Edited by Jeff Sahadeo and Russell Zanca. Bloomington, IN: Indiana University Press, 319-338 p.

Absalyamova, Y.A. (2019). The Cult of Sacred Springs among the Bashkir. Shaman. Budapest, 27, 1-2, 45-53.

Akbar, I., Yang, Z., Mazbayev, O., Seken, A., \& Udahogora, M. (2020). Local residents participation in tourism at a world heritage site and limitations: AksuJabagly state nature reserve, Western Tian-Shan, Kazakhstan. GeoJournal of Tourism and Geosites, 28(1), 35-51. https://doi.org/10.30892/gtg.28103-450

Akhmedenov, K.M., \& Idrisova, G.Z. (2018). Springs of Western Kazakhstan as objects of sacred geography. Eurasian crossroads. Collection of materials for scientific and practical events. Orenburg, 8, 290-295.

Akhmedenov, K.M., \& Idrissova G.Z. (2019). Springs of Western Kazakhstan as prospective features of religious tourism. Bulletin of the West Kazakhstan State University, 2, 462-475.

Akhmedenov, K.M., Iskaliev, D.Z., \& Akhmedenova, S.G. (2013). Factors of the spring waters formation and the evolution of spring areas of West Kazakhstan. Life Science Journal, 10 (12s), 710-720. https://doi.org /10.7537/marslsj1012s13.113

Anisimova, I. (2008). Miraculous orthodox sources of Russian. Moscow, RIPOL Klassik, 190 p.

Ascoura, I.S. (2013). Impact of Pilgrimage (Hajj) on the Urban Growth of the Mecca. Journal of Educational and Social Research, 3(2) May. https://doi.org/ 10.5901/jesr. 2013.v3n2p255

Baranchikov, E.V. (2019). Historical and cultural and religious tourism in Iran. Geographical problems and opportunities for tourism and recreation development in Uzbekistan. Proceedings of the International scientific and practical conference (Chirchik, October 11-12, 2019), 38-41.

Basilov, V.N. (1992). Shamanism among the peoples of Central Asia and Kazakhstan. M., 328 p.

Bedula, O.I. (2010). Holy springs of the Samara region. Live springs. Samara, 112 p.

Beketova, A., Berdenov, Z., Mendybayev, E., Safarov, R., Shomanova, Zh., \& Herman, G.V. (2019). Geochemical monitoring of industrial center for development of recreational areas (on the example of Khromtau-don industrial hub, Kazakhstan). GeoJournal of Tourism and Geosites, 27(4), 1449-1463. https://doi.org/10.30892/gtg.27428-447

Belohvostikov, E.P. (2007). Holy springs of Penza land. Penza, 134 p.

Bukharova, G.Kh. (2017). The Reflection of Muslim religious beliefs of the Bashkirs in toponymy. Culture and Civilization, 7 (6A), $7-15$.

Bunakov, O.A., Eidelman, B.M., Aslanova, D.K., Zaitseva, N.A., Larionova, A.A., \& Chudnovskiy, A.D. (2019). Religious and halal tourism organization peculiarities in muslim republics. European Journal of Science and Theology, 15, 3, 85-96.

Di Puppo, L., \& Schmoller, J. (2019). The Revival of Sacred Sites in the Urals: The Local and Beyond. 13. 143-145. https://doi.org/10.2478/jef-2019-0023.

Edelbay, S. (2012). Traditional Kazakh Culture and Islam. International Journal of Business and Social Science, 3, 11, $122-133$.

Idiatullov, A.K. (2018). "Sacred" objects of tatars and bashkirs of the Middle Volga and Ural Regions. Bulletin of Tomsk state University. History, 52, 89-94.

Idrissova, G.Z., Akhmedenov, K.M., Sergeeva, I.V., Ponomareva, A.L., \& Sergeeva, E.S. (2017). Monitoring studies of the ecological state of springs in the Aktobe region in Western Kazakhstan. Journal of Pharmaceutical Sciences and Research, 9 (7), 1122-1127.

Ivanova, M.V., Sazonkina, L.V., \& Polynova, L.A. (2018). Tourist regional studies. Western and Northern Europe. Japan, Moscow, Yurait Publishing House, 465 p.

Jørgensen, N.N., Eade, J., Ekeland, T.J., \& Lorentzen, C.A.N. (2020). The Processes, Effects and Therapeutics of Pilgrimage Walking the St. Olav Way. International Journal of Religious Tourism and Pilgrimage, 8,1, 6. https://doi.org/10.21427/v0cc-7135

Kabdrakhmanova, N.K, Mussabayeva, M.N., Atasoy, E., Zhensikbayeva, N.Z., \& Kumarbekuly S. (2019). Landscape and recreational analysis of Yertis river upper part on the basis of basin approach (Kazakhstan). GeoJournal of Tourism and Geosites, 27(4), 1392-1400. https://doi.org/10.30892/gtg.27423-442

Katkova, E.G., Oborin, M.S., \& Klimova, O.V. (2013). Recreational potential of springs on the territory of the Altai Mountains. Bulletin of the Northern (Arctic) Federal University. Series: Natural Sciences, 1, 5-9.

Kerimbay, B.S., Janaleyeva, K.M., \& Kerimbay, N.N. (2020). Tourist and recreational potential of landscapes of the specially protected natural area of Sharyn of the Republic of Kazakhstan. GeoJournal of Tourism and Geosites, 28(1), 67-79. https://doi.org/10.30892/gtg.28105-452

Konshin, N.Ya. (1901). From Pavlodar to Karkaralinsk. Travel sketches. Memorial book of the Semipalatinsk region. Semipalatinsk, 26 p.

Koshim, A., Sergeyeva, A., Saparov, K., \& Wendt, J.A. (2019). Development of scientific tourism at Baikonur Cosmodrome Kazakhstan. GeoJournal of Tourism and Geosites, 24 (1), 267-279. https://doi.org/10.30892/gtg.24121-358

Koshim, A.G., Sergeyeva, A.M., Bexeitova, R.T., \& Aktymbayeva A.S. (2020). Landscape of the Mangystau region in Kazakhstan as a geomorphotourism destination: a geographical review. GeoJournal of Tourism and Geosites, 29(2), 385-397. https://doi.org/10.30892/gtg.29201-476

Krylov, A.N. (2011). Sacral tourism in the concepts of the development of cities and regions. Competitive potential of the region: assessment and efficiency of use. Collection of articles of the international scientific-practical conference, November 10-12, Abakan. -Abakan: Publishing house of FSBEI HPE Khakass State University. N.F. Katanova, 14-16.

Kubesova, G.T. (2015). Natural recreational resources of Western Kazakhstan. Moscow: LAP Lambert Academic Publishing, 116 p.

Kuznecova, E.V., Fahrutdinov, R.R., \& Fahrutdinov B. (2019). Tourist directions and routes of the sacred and pilgrims in the Ulyanovsk region. International Journal on Emerging Technologies, 10, 2, 158-159.

Larina, E.I. (2016). Materials for the Study of the Cult of Saints among the Kazakhs (Evidence from West Kazakhstan Region). Bulletin of the Kalmyk Institute for Humanities of the Russian Academy of Sciences, 27, 5, 108-117.

Levshin, A.I. (2007). Description of Kazakh hordes and steppes. 2nd ed. Additional Astana: Altyn kitap, 9, 38.

Lymer, K. (2004). Rags and rock art: the landscapes of holy site pilgrimage in the Republic of Kazakhstan. World Archaeology, 36(1), 158-172. https://doi.org/10.1080/0043824042000192605

Mazhitova, G.Z., Pashkov, S.V., \& Wendt J.A. (2018). Assessment of landscape-recreational capacity of North Kazakhstan region. GeoJournal of Tourism and Geosites, 23(3), 731-737. https://doi.org/10.30892/gtg.23309-323

McIntosh, I., Schlee, C., \& Munro, D. (2020). New Directions in Sacred Journeys Research. International Journal of Religious Tourism and Pilgrimage, 8, 1, 2. https://doi.org/10.21427/3crm-tg68.

Novyh, L.L., \& Demchenko, S.V. (2013). The Geoecological approach in the study of springs. Socio-ecological education of studying youth: problems and prospects. Collection of scientific articles, 3, Belgorod, 215-222.

Orekhova, G.A., Novykh, L.L., Naumov, O.N., Vasilchenko, A.P., Storozhenko, E.A., \& Toropova, A.V. (2016). Holy springs of Belogorye as perspective objects of religious tourism. 1. The current state of the saints springs. Belgorod State University Scientific Bulletin. Natural sciences, 25 (218), $37,179-187$.

Orekhova, G.A., Novykh, L.L., Naumov, O.N., Vasilchenko, A.P., \& Storozhenko, E.A. (2017). Holy springs of Belogorye as perspective objects of religious tourism. 2. Recreational and cult evaluation of the springs. Belgorod State University Scientific Bulletin. Natural sciences, 4 (253), $38,169-178$.

Petin, A.N., \& Novyh, L.L. (2009). Springs of Belogoriye. Belgorod, CONSTANTA, 220 p.

Potapov, L.P. (1991). Elements of religious beliefs in ancient Turkic genealogical legends. Soviet Ethnography, 5, 81.

Poyarkov, F.V. (1891). From the area of Kyrgyz beliefs. Ethnographic review, IX. 4, 41-43.

Rakhimov, R.R., \& Terletsky, N.S. (2006). "Live" springs and wells of Central Asia. Radlovsky readings-2006. Abstracts (Saint Petersburg, 2006), 176-183.

Ramazanov, S.K., Tereshchenko, T.A., \& Abdusheva, G.Zh. (2003). Recreational landscapes of the West Kazakhstan region. Materials of the international scientific and practical conference. Development of the national economy in Western Kazakhstan: potential, problems and prospects, dedicated to the 40th anniversary of the West Kazakhstan agrotechnical University, Uralsk, $121 \mathrm{p}$. 
Serak, O.O. (2017). Holy springs of the Eastern Crimea as objects of pilgrimage tourism. Modern scientific research and innovation, 2 [Electronic resource]. URL: http://web.snauka.ru/issues/2017/02/78354 (date accessed: 02.02.2020).

Sergeeva, A.M. (2011). Physiography of Aktobe region for the development of ecotourism. Bulletin of The Treasury. Geographical series, 1 (32), $30-36$. Shulembayev, K.Sh. (1975). Magicians, gods and reality (General and special in the religious beliefs of the Kazakhs). Almaty: Kazakhstan Publishing House, 1975, 128 p.

Shvets, V.M., Lisenkov, A.B., \& Popov, E.V. (2002). Springs of Moscow. M: Scientific world, 160 p.

Sivokhip, J.T. (2005). Springs zoning and its results usage at estimating the recreational potential of the territory (on the example of the Orenburg region). Povolzhskiy Journal of Ecology, 2, 158-166.

Stasevich, I.V. (2012). The practice of worshipping sacred objects and objects in the traditional and modern culture of Kazakhs and Kirghizs (in the context of studying the cult of saints). Central Asia: tradition in the face of change, Saint Petersburg, 3, 270-301.

Terletskiy, N.S. (2007). Places of pilgrimage and venerations in the context of pre-Islamic traditions of Central Asia. Central Asia. Traditions in the changing world, I, Saint Petersburg, Nauka Publ., 71-98.

Terletsky, N.S. (2009). Some ancient attributes of Muslim places of pilgrimage and worship (to the question of the functions and symbolism of the tug). Central Asia. Traditions in the changing world, II, Saint Petersburg, Nauka Publ., 113-114.

Tokhtabayeva, Sh.Zh. (2017). Kazakhs 'etiquette norms. Part I. Weekdays and holidays. Almaty: EPUB, 400 p.

Tovmasyan, G.R. (2016). Religious tourism development bases and perspectives in the Republic of Armenia. Actual problems of the humanities and natural sciences, 1-3, 7-10.

Triki, M.B. (2019). The role of religious tourism in sustainable development in Saudi Arabia: evidence from quantile non-causality test. GeoJournal of Tourism and Geosites, 27(4), 1321-1333. https://doi.org/10.30892/gtg.27417-436

Wilson, K. (2020). Place and Space in Walking Pilgrimage. International Journal of Religious Tourism and Pilgrimage, 8, 1, 3. https://doi.org/10.21427/8g72-ev39

Yegemberdiyeva, K.B., Yushina, Yu. A., \& Orazbekova, K.S. (2018). Main stages of tourist routes development for different types of environmental tourism (on the example of the Mangystau Region). Issues of Geography and Geoecology, 1, 89-98.

Yessimova, D.D., Tsaregorodtseva, A.G., Azhaev, G.S., \& Arefev, V.E. (2016). Conceptual foundations of tourism development in North-Eastern Kazakhstan and the Altai territory: monograph, Almaty: Evero publishing house, $216 \mathrm{p}$.

Zhupankhan A., Tussupova K., \& Berndtsson R. (2018). Water in Kazakhstan, a key in Central Asian water management, Hydrological Sciences Journal, 63(5), 752762. https://doi.org/10.1080/02626667.2018.1447111

*** MFA (Ministry of Foreign Affairs of the Republic of Kazakhstan) (2016). Water security - vital to peace, vital to progress. Electronic resource: http://www.kazakhstanunsc.com/policypriori ties/water-security (accessed in April 20, 2020).

*** SanPiN RK (2015). Sanitary and epidemiological requirements for water sources, places of water intake for economic and drinking purposes, economic and drinking water supply and places of cultural and household water use and water safety (March 16, 2015, No. 209), Astana, 137 p.

Article history:

Received: 11.03.2020

Revised: 04.06.2020

Accepted: 10.07.2020

Available online: 31.07 .2020 